\title{
FAKTOR YANG BERKONTRIBUSI TERHADAP MOTIVASI MENJALANI PEMERIKSAAN PAP SMEAR PASIEN KANKER SERVIKS DI POLI KANDUNGAN
}

\author{
Latifah, $\mathbf{H j}^{1}$, Nurachmah, Elly ${ }^{2}$, Hiryadi ${ }^{3}$ \\ ${ }^{1}$ Mahasiswa Pascasarjana Ilmu Keperawatan Universitas Muhammadiyah Banjarmasin, 70114, \\ Indonesia \\ ${ }^{2}$ Staff Dosen Fakultas Keperawatan Universitas Indonesia, 16424, Indonesia \\ ${ }^{3}$ Staff Dosen Pascasarjana Universitas Muhammadiyah Banjarmasin, 70114, Indonesia
}

Email: hajjahlatifah69@gmail.com

\begin{abstract}
ABSTRAK
Latar Belakang: Kanker serviks adalah penyakit keganasan leher rahim dimana setiap harinya ada 40 orang terdiagnosa kanker serviks di Indonesia dan 20 orang diantaranya meninggal dunia. Kalimantan Selatan tahun 2018 tercatat ada 53 orang penderita baru dan 1.877 orang penderita lama. Sekitar 70\% penderita baru datang berobat dalam stadium > IIB. Pemeriksaan pap smear adalah cara deteksi dini yang dapat mengurangi angka kejadian dan kematian akibat kanker serviks. Penelitian ini bertujuan untuk mengidentifikasi faktor yang berkontribusi terhadap motivasi menjalani pemeriksaan pap smear pada pasien kanker serviks.

Metode: Penelitian ini menggunakan desain kuantitatif dengan pendekatan cross sectional, Sampel yang digunakan sebanyak 43 orang dengan teknik purposive sampling. Instrumen yang digunakan adalah kuesioner.

Hasil: Faktor pengetahuan, sikap, dukungan suami dan dukungan petugas kesehatan berkontribusi terhadap motivasi menjalani pemeriksaan pap smear pada pasien kanker serviks. Faktor yang paling berkontribusi terhadap motivasi menjalani pemeriksaan pap smear pada pasien kanker serviks. Lebih meningkatkan motivasi pasien kanker serviks dalam menjalani pemeriksaan pap smear.

Kesimpulan: Promosi kesehatan dalam pemberdayaan masyarakat khususnya tentang pemeriksaan dini untuk meningkatkan motivasi pasien kanker serviks perlu ditingkatkan kembali. Pelayanan kesehatan juga diharapkan dapat mengoptimalkan kegiatan seperti memberikan penyuluhan tentang pemeriksaan dini terhadap wanita usia subur, memberikan informasi tentang penyebab dan pencegahan kanker serviks, serta meningkatkan motivasi pasien kanker serviks dalam melakukan pemeriksaan pap smear.
\end{abstract}

Kata Kunci : Pengetahuan, Sikap, Dukungan Suami, Dukungan Petugas Kesehatan, Motivasi Pemeriksaan Pap Smear 


\section{PENDAHULUAN}

Kasus kanker serviks di Indonesia menempati peringkat pertama dengan jumlah kasus 14.368 orang dan dari jumlah tersebut sebanyak 7.297 orang meninggal dengan prevalensi 10.823 orang setiap tahunnya. Kanker yang merupakan tumor ganas pada leher rahim perempuan ini merupakan pembunuh nomor satu bagi perempuan Indonesia. Penderita kanker serviks sangat tinggi, setiap tahun tidak kurang dari 15.000 kasus terjadi di Indonesia. Jumlah wanita yang dilakukan skrining dengan sasaran wanita usia subur (WUS) 30-50 tahun hanya sebanyak 644.951 WUS atau sebesar 1,75 persen dan sebanyak 28.850 WUS atau sebesar 4,47 persen (1,3 per 1000 WUS yang diskrining) diantaranya IVA positif atau curiga kanker serviks.

Mengacu pada data dari Dinas Kesehatan Provinsi Kalimantan Selatan tahun 2016 tercatat penderita kanker serviks di Kalimantan Selatan sebanyak 50 orang. Terjadi peningkatan angka kejadian kanker serviks di Kal-Sel pada tahun 2018 dimana tercatat penderita kanker serviks yang melakukan kunjungan pertama untuk melakukan pemeriksaan dini sebanyak 53 orang dan yang melakukan kunjungan kedua atau lebih sebanyak 1.877 penderita kanker serviks (Dinkes Provinsi Kalimantan Selatan, 2019). Penderita kanker serviks stadium 1 memiliki angka harapan hidup antara $80-93 \%$, penderita stadium 2 memiliki angka harapan hidup antara $58-63 \%$, penderita stadium stadium 3 memiliki angka harapan hidup antara $32-35 \%$ dan penderita stadium stadium 4 memiliki angka harapan hidup antara15-16\%.

RSUD Ulin Banjarmasin tahun 2018 memperlihatkan jumlah pasien yang menderita kanker serviks di Ruang Nifas sebanyak 108 orang, sedangkan pada tahun 2019 dari bulan Maret sampai Juni didapatkan sebanyak 50 orang penderita kanker serviks. Data yang didapatkan pada Poliklinik Kandungan RSUD Ulin Banjarmasin tahun 2018 dari bulan Juni sampai Desember jumlah pasien yang terdiagnosa kanker serviks sebanyak 887 orang dan pada tahun 2019 dari bulan Januari sampai Mei terdapat 560 penderita kanker serviks (Dokumen: RSUD Ulin Banjarmasin, 2019).

Tingginya angka kematian penderita kanker serviks di Indonesia disebabkan penderita kanker serviks baru datang berobat setelah stadium lanjut, sekitar $70 \%$ penderita datang dalam stadium lanjut (> stadium IIB). Kondisi ini karena kurangnya kesadaran atau tidak adanya motivasi untuk melakukan deteksi dini kanker serviks, padahal jika diobati sedini mungkin, hasilnya akan lebih baik. Nah, cara terbaik untuk mendeteksi kanker serviks secara dini adalah dengan melakukan tes Pap smear

Pap smear merupakan pemeriksaan mikroskopis terhadap sel yang diambil dari mulut rahim (serviks). Pap smear dapat mendeteksi perubahan pada sel-sel serviks akibat infeksi virus tertentu seperti human papilloma virus (HPV), yang diketahui menyebabkan kanker serviks. Ketika perubahan prakanker diketahui dan diobati secara dini, maka kanker serviks dapat diatasi sebelum berkembang sepenuhnya. Banyak wanita yang akhirnya meninggal karena tidak menyadari bahwa dirinya memiliki kanker serviks, karena pada tahap awal tidak mengalami gejala apa pun. Begitu bergejala, maka kondisinya sudah berat dan sulit untuk di tolong, dengan pemeriksaan Pap smear ini, diharapkan insiden kanker dan kematian akibat kanker serviks dapat menurun secara signifikan, karena ketika hasil Pap smear menunjukkan ketidaknormalan, maka observasi dan tindakan yang tepat dapat dengan cepat dilakukan (Ramadini, 2018).

Pemeriksaan Pap smear untuk deteksi dini kanker serviks di Indonesia juga masih sangat rendah yaitu hanya sekitar 5\% dari wanita usia subur yang sudah menikah, masih sangat jauh dari cakupan deteksi dini yang efektif. Cakupan deteksi dini yang efektif dalam menurunkan angka kesakitan dan angka kematian karena kanker serviks adalah sebesar $85 \%$ dari jumlah sasaran wanita usia subur yang sudah menikah, padahal lebih dari 3.700 puskesmas di Indonesia saat ini telah dilatih dalam memberikan pelayanan deteksi dini kanker leher rahim (Kemenkes RI, 2017).

Motivasi merupakan proses psikologi dalam diri seseorang dan sangat dipengaruhi oleh berbagai faktor. Secara umum, faktor ini dapat muncul dari dalam diri (intrinsik). Faktor dari dalam diri (intrinsik) merupakan motivasi yang muncul tidak perlu dirangsang dari luar karena dalam diri setiap manusia sudah ada dorongan untuk melakukan sesuatu seperti pengetahuan dan sikap. Pengetahuan yang dimiliki tentang kanker serviks akan 
membentuk suatu keyakinan dan menjadi motivasi internal untuk melakukan perilaku pencegahan kanker serviks salah satunya pemeriksaan Pap smear, namun beberapa penelitian menunjukan bahwa masih banyak wanita usia subur yang memiliki pengetahuan kurang tentang kanker serviks dan pemeriksaan Pap smear. Hasil penlitian Miftahil Fauza et, all (2019) menemukan dalam penelitiannya bahwa lebih dari setengah wanita usia subur (WUS) $58,7 \%$ dalam penelitiannya memiliki pengetahuan kurang tentang kanker serviks, dalam penelitiannya juga terungkap bahwa ada hubungan pengetahuan dengan pemeriksaan Pap smear.

Demikian juga halnya akan sikap, terutama bagi perempuan yang memiliki pandangan bahwa kanker serviks merupakan suatu penyakit yang sangat berbahaya baginya dan dapat dicegah sedini mungkin akan dapat menimbulkan motivasi internal untuk melakukan pemeriksaan pap smear dalam upaya pencegahan penyakit tersebut. Perempuan ini akan menunjukkan sikap berkeinginan untuk diperiksa lebih jauh. Terkait pengaruh sikap terhadap motivasi pemeriksaan Pap smear Idaria Sidabukke et, all (2017) mengungkapkan dalam penelitiannya ada hubungan sikap dengan minat WUS melakukan pemeriksaan deteksi dini kanker serviks.

Faktor yang menimbulkan motivasi dalam pemeriksaan Pap smear juga dapat dirangsang dari luar diri (ekstrinsik) seperti motivasi yang muncul karena adanya dukungan suami berupa perhatian suami untuk meminta istri melakukan pemeriksaan dini kanker serviks Pap smear, suami menemani dalam pemeriksaan Pap smear dan lain sebagainya sehingga isteri mau melakukan pemeriksaan Pap smear, hal ini didukung hasil penelitian yang dilakukan oleh Rayhana \& Hatfina Izzati (2016) menunjukan peran suami yang signifikan dalam memberikan motivasi untuk melakukan pemeriksaan Pap smear. Faktor ekstrinsik lainnya diantaranya dukungan tenaga kesehatan dalam bentuk penyuluhan untuk mengajak wanita usia subur yang sudah menikah turut serta dalam pemeriksaan kesehatan reproduksi seperti pemeriksaan pap smear. Demikian pula pemerintah atau organisasi yang terlibat dalam pencegahan kanker seperti Yayasan Kanker Indonesia yang melakukan upaya promosi kesehatan dan pencegahan penyakit kanker melalui berbagai media.

Hasil studi pendahuluan yang dilakukan peneliti di Poliklinik Kandungan RSUD Ulin Banjarmasin terkait pemeriksaan dini kanker serviks pap smear yang dilakukan melalui wawancara kepada pasien rawat jalan yang berusia 21-40 tahun pada tanggal 2-4 Oktober 2019 sebanyak 14 orang hampir seluruhnya yaitu sebanyak 11orang $(78,5 \%)$ tidak pernah melakukan pemeriksaan kanker serviks pap smear. Pada wawancara lebih mendalam kepada 11 orang tersebut, mereka menyatakan bahwa tidak mengetahui tentang pap smear, takut dilakukan pemeriksaan, tidak mendapat dukungan dari suami dan tidak memahami informasi yang disampaikan oleh petugas puskesmas di daerahnya terkait pemeriksaan kanker serviks pap smear.

\section{METODE PENELITIAN}

Penelitian ini merupakan penelitian kuantitatif dengan rancangan cross sectional. Populasi dalam penelitian ini adalah seluruh pasien kanker serviks stadium I di Poliklinik Kandungan RSUD Ulin Banjarmasin yang rutin kontrol sampai dalam 6 bulan terakhir sebanyak 290 orang dengan rata-rata perbulan berjumlah 48 orang. Sampel pada penelitian ini adalah sebagian dari populasi berjumlah 43 orang yang ditentukan menggunakan rumus Slovin dengan teknik sampling purposive sampling. Data dianalisis secara univariat, bivariate dan multivariate dengan menggunakan uji statistik Spearman's rho dan regresi logistik berganda.

\section{HASIL}

\section{Pengetahuan}

Tabel 1. Distribusi Pengetahuan Responden di Poliklinik Kandungan RSUD Ulin Banjarmasin.

\begin{tabular}{|clcc|}
\hline No & Pengetahuan & Jumlah & Persentasi \\
\hline 1 & Baik & 24 & 55,8 \\
\hline 2 & Kurang Baik & 19 & 44,2 \\
\hline Jumlah & 43 & 100 \\
\hline
\end{tabular}

Berdasarkan tabel 1. Didapatkan 24 responden $(55,8 \%)$ memiliki pengetahuan baik terhadap pemeriksaan pap smear.

\section{Sikap}

Tabel 2. Distribusi Sikap Responden di Poliklinik Kandungan RSUD Ulin Banjarmasin 


\begin{tabular}{|cccc|}
\hline No & Sikap & Jumlah & Persentasi \\
\hline 1 & Positif & 22 & 51,2 \\
\hline 2 & Negatif & 21 & 48,8 \\
\hline Jumlah & 43 & 100 \\
\hline
\end{tabular}

Berdasarkan tabel 2. Didapatkan 22 responden $(51,2 \%)$ yang mempunyai sikap positif terhadap pemeriksaan pap smear.

\section{Dukungan Suami}

Tabel 3. Distribusi Dukungan Suami Responden di Poliklinik Kandungan RSUD Ulin Banjarmasin

\begin{tabular}{|cccc|}
\hline No & $\begin{array}{c}\text { Dukungan } \\
\text { Suami }\end{array}$ & Jumlah & Persentasi \\
\hline 1 & Baik & 36 & 83,7 \\
\hline 2 & Kurang Baik & 7 & 16,3 \\
\hline Jumlah & 43 & 100 \\
\hline
\end{tabular}

Berdasarkan tabel 3. Didapatkan 36 responden $(83,7 \%)$ yang mendapat dukungan baik dari suami untuk melakukan pemeriksaan pap smear.

\section{Dukungan Petugas Kesehatan}

Tabel 4. Distribusi Dukungan Petugas Kesehatan di Poliklinik Kandungan RSUD Ulin Banjarmasin

\begin{tabular}{|cccc|}
\hline No & $\begin{array}{c}\text { Dukungan } \\
\text { Petugas } \\
\text { Kesehatan }\end{array}$ & Jumlah & Persentasi \\
\hline 1 & Baik & 38 & 88,4 \\
\hline 2 & Kurang Baik & 5 & 11,6 \\
\hline Jumlah & 43 & 100 \\
\hline
\end{tabular}

Berdasarkan tabel 4. Didapatkan 38 responden (88,4\%) yang mendapat dukungan baik dari petugas kesehatan untuk melakukan pemeriksaan pap smear .

\section{Motivasi}

Tabel 5. Distribusi Motivasi Responden di Poliklinik Kandungan RSUD Ulin Banjarmasin

\begin{tabular}{|cccc|}
\hline No & Motivasi & Jumlah & Persentasi \\
\hline 1 & Tinggi & 36 & 83,7 \\
\hline 2 & Rendah & 7 & 16,3 \\
\hline Jumlah & 43 & 100 \\
\hline
\end{tabular}

Berdasarkan tabel 5. Didapatkan 36 responden $(83,7 \%)$ responden yang mempunyai motivasi tinggi untuk melakukan pemeriksaan pap smear.

Kontribusi Pengetahuan terhadap Motivasi Menjalani Pemeriksaan Pap Smear pada
Pasien Kanker Serviks di Poliklinik Kandungan RSUD Ulin Banjarmasin.

Tabel 6. Kontribusi Pengetahuan terhadap Motivasi Menjalani Pemeriksaan Pap Smear pada Pasien Kanker Serviks di Poliklinik Kandungan RSUD Ulin Banjarmasin.

\begin{tabular}{|c|c|c|c|c|c|c|c|}
\hline \multirow{3}{*}{ No } & \multirow{3}{*}{ Pengetahuan } & \multicolumn{6}{|c|}{ Motivasi } \\
\hline & & \multicolumn{2}{|c|}{ Tinggi } & \multicolumn{2}{|c|}{ Rendah } & \multicolumn{2}{|c|}{ Jumlah } \\
\hline & & $\mathrm{n}$ & $\%$ & $\mathrm{n}$ & $\%$ & $\mathrm{~N}$ & $\%$ \\
\hline 1 & Tinggi & 22 & 91,7 & 2 & 8,3 & 24 & 100 \\
\hline 2 & Rendah & 14 & 73,3 & 5 & 26,3 & 19 & 100 \\
\hline \multicolumn{2}{|c|}{ Jumlah } & 36 & 83,7 & 7 & 16,3 & 100 & 100 \\
\hline \multicolumn{8}{|c|}{$\begin{array}{l}\text { Sperman's rho } \mathrm{p}=0,048<\mathrm{a}=0,05 \text { (Korelasi Koefisien } \\
=0,242 \text { ) }\end{array}$} \\
\hline
\end{tabular}

Tabel 6. Menunjukkan bahwa pada responden dengan pengetahuan tinggi $22(91,7 \%)$ responden dan motivasi rendah 2 (8,3\%) responden, hal ini menyatakan bahwa semakin tinggi pengetahuan responden tentang kanker servik maka semakin tinggi motivasi responden untuk melakukan pemeriksaan pap smear.
Kontribusi Sikap terhadap Motivasi Menjalani Pemeriksaan Pap Smear pada Pasien Kanker Serviks di Poliklinik Kandungan RSUD Ulin Banjarmasin.

Tabel 7. Kontribusi Sikap terhadap Motivasi Menjalani Pemeriksaan Pap Smear pada Pasien Kanker Serviks di Poliklinik Kandungan RSUD Ulin Banjarmasin.

\begin{tabular}{|c|c|c|c|c|c|c|c|}
\hline \multirow{3}{*}{ No } & \multirow{3}{*}{ Sikap } & \multicolumn{6}{|c|}{ Motivasi } \\
\hline & & \multicolumn{2}{|c|}{ Tinggi } & \multicolumn{2}{|c|}{ Rendah } & \multicolumn{2}{|c|}{ Jumlah } \\
\hline & & $\mathrm{n}$ & $\%$ & $\mathrm{n}$ & $\%$ & $\mathrm{~N}$ & $\%$ \\
\hline 1 & Positif & 21 & 95,5 & 1 & 4,5 & 24 & 100 \\
\hline 2 & Negatif & 15 & 71,4 & 6 & 28,6 & 19 & 100 \\
\hline \multicolumn{2}{|c|}{ Jumlah } & 36 & 83,7 & 7 & 16,3 & 100 & 100 \\
\hline \multicolumn{8}{|c|}{$\begin{array}{l}\text { Sperman's rho } \mathrm{p}=0,033<\mathrm{a}=0,05 \text { (Korelasi Koefisien } \\
=0,326)\end{array}$} \\
\hline
\end{tabular}


Tabel 7. Menunjukkan bahwa pada responden sebagian besar memiliki sikap positif yaitu $95,5 \%$.

Kontribusi Dukungan Suami terhadap Motivasi Menjalani Pemeriksaan Pap Smear pada Pasien Kanker Serviks di Poliklinik Kandungan RSUD Ulin Banjarmasin.

Tabel 8. Kontribusi Dukungan Suami terhadap Motivasi Menjalani Pemeriksaan Pap Smear pada Pasien Kanker Serviks di Poliklinik Kandungan RSUD Ulin Banjarmasin.

\begin{tabular}{|c|c|c|c|c|c|c|c|}
\hline \multirow{3}{*}{ No } & \multirow{3}{*}{$\begin{array}{c}\text { Dukungan } \\
\text { Suami }\end{array}$} & \multicolumn{6}{|c|}{ Motivasi } \\
\hline & & \multicolumn{2}{|c|}{ Tinggi } & \multicolumn{2}{|c|}{ Rendah } & \multicolumn{2}{|c|}{ Jumlah } \\
\hline & & $\mathrm{n}$ & $\%$ & $\mathrm{n}$ & $\%$ & $\mathrm{~N}$ & $\%$ \\
\hline 1 & Baik & 34 & 94,4 & 2 & 5,6 & 36 & 100 \\
\hline 2 & $\begin{array}{l}\text { Kurang } \\
\text { Baik }\end{array}$ & 2 & 28,6 & 5 & 71,4 & 7 & 100 \\
\hline \multicolumn{2}{|c|}{ Jumlah } & 36 & 83,7 & 7 & 16,3 & 100 & 100 \\
\hline \multicolumn{8}{|c|}{$\begin{array}{l}\text { Sperman's rho } \mathrm{p}=0,000<\mathrm{a}=0,05 \text { (Korelasi Koefisien } \\
=0,659 \text { ) }\end{array}$} \\
\hline
\end{tabular}

Tabel 8. Menunjukkan pada responden yang memiliki dukungan suami baik sebanyak 34 $(94,4 \%)$ responden motivasi tinggi dan sebanyak 2 responden $(5,6 \%)$ motivasi rendah, hal ini menyatakan semakin baik dukungan suami terhadap responden untuk mendampingi pemeriksaan maka akan semakin tinggi motivasi responnden untuk melakukan pemeriksaan pap smear.

Kontribusi Dukungan Petugas Kesehatan terhadap Motivasi Menjalani Pemeriksaan Pap Smear pada Pasien Kanker Serviks di Poliklinik Kandungan RSUD Ulin Banjarmasin.

Tabel 9. Kontribusi Dukungan Petugas Kesehatan terhadap Motivasi Menjalani Pemeriksaan Pap Smear pada Pasien Kanker Serviks di Poliklinik Kandungan RSUD Ulin Banjarmasin.

\begin{tabular}{|cccccccc|}
\hline \multirow{2}{*}{ No $\begin{array}{c}\text { Dukungan } \\
\text { Petugas } \\
\text { Kesehatan }\end{array}$} & \multicolumn{6}{c|}{ Motivasi } \\
\cline { 2 - 8 } & $\mathrm{n}$ & $\%$ & $\mathrm{n}$ & $\%$ & $\mathrm{~N}$ & $\%$ \\
\hline 1 & Baik & 36 & 94,7 & 2 & 5,3 & 38 & 100 \\
\hline 2 & $\begin{array}{l}\text { Kurang } \\
\text { Baik }\end{array}$ & 0 & 0 & 5 & 100 & 5 & 100 \\
\hline Jumlah & 36 & 83,7 & 7 & 16,3 & 100 & 100 \\
\hline $\begin{array}{l}\text { Sperman's } \text { rho } \mathrm{p}=0,000<\mathrm{a}=0,05 \\
=0,659)\end{array}$ \\
\end{tabular}

Tabel 9. Menunjukkan bahwa pada responden yang memiliki dukungan petugas kesehatan baik sebanyak 36 responden $(94,7 \%)$ motivasi tinggi dan sebanyak 2 responden $(5,3 \%)$ motivasi rendah, hal ini menyatakan semakin baik dukungan petugas kesehatan terhadap responden maka semakin tinggi motivasi responden untuk melakukan pemeriksaan pap smer.

Faktor yang paling berkontribusi terhadap motivasi menjalani pemeriksaan pap smear pada pasien kanker serviks di Poliklinik Kandungan RSUD Ulin Banjarmasin

Tabel 10. Faktor yang Paling Berkontribusi terhadap Motivasi Menjalani Pemeriksaan Pap Smear pada Pasien Kanker Serviks di Poliklinik Kandungan RSUD Ulin Banjarmasin.

\begin{tabular}{|clcc|}
\hline No & \multicolumn{1}{c}{ Variabel } & p Value & $\begin{array}{c}\text { Korelasi } \\
\text { Koefisien }\end{array}$ \\
\hline 1 & Pengetahuan & 0,048 & 0,242 \\
\hline 2 & Sikap & 0,033 & 0,325 \\
\hline 3 & Dukungan Suami & 0,000 & 0,659 \\
\hline & $\begin{array}{l}\text { Dukungan Petugas } \\
\text { Kesehatan }\end{array}$ & 0,000 & 0,823 \\
\hline
\end{tabular}

Berdasarkan tabel 10. Dengan melihat masingmasing nilai $\rho$ value variabel pengetahuan, sikap, dukungan suami dan dukungan petugas kesehatan memiliki nilai signifikansi $<0,025$, artinya variabel dependen tersebut memiliki kontribusi terhadap motivasi menjalani pemeriksaan pap smear secara signifikan, berdasarkan nilai korelasi koefisien menurut Coltont untuk variabel pengetahuan diperoleh nilai 0,242 yakni kontribusi pengetahuan terhadap motivasi rendah, variabel sikap diperoleh nilai 0,325 yakni kontribusi sikap terhadap motivasi sedang, variabel dukungan suami diperoleh nilai 0,659 yakni kontribusi dukungan suami terhadap motivasi kuat dan variabel dukungan petugas kesehatan diperoleh nilai 0,823 yakni kontribusi dukungan petugas kesehatan terhadap motivasi sangat tinggi.

\section{PEMBAHASAN}

Pengetahuan tentang Penyakit Kanker Serviks dan Pemeriksaan Pap Smear pada Pasien Kanker Serviks di Poliklinik Kandungan RSUD Ulin Banjarmasin.

Hasil penelitian pengetahuan tentang penyakit kanker serviks dan pemeriksaan pap smear dari 43 responden ditemukan $24(55,8 \%)$ responden yang memiliki pengetahuan baik dan $19(44,2 \%)$ responden memilik pengetahuan 
kurang baik. Penelitian ini, pengetahuan responden paling banyak rendah tentang penyakit kanker serviks dan pemeriksaan kanker serviks pap smear dan sisanya tinggi, bila diperhatikan lebih dalam dan dikaitkan dengan pendidikan responden, maka dapat dimengerti bahwa pengetahuan responden tentang penyakit kanker serviks dan pemeriksaan pap smear rendah karena ibu yang menjadi responden dalam penelitian ini rata-rata memiliki pendidikan menengah ke bawah dan hanya sebagian kecil yang memiliki pendidikan menengah ke atas.

Ada hubungan yag signifikan antara tingkat pengetahuan wanita usia subur dengan motivasi melakukan pemeriksaan pap smear di Desa Jetis Wilayah Kerja Puskesmas Jimbaran. Sinta Oktavyany (2015), menambahkan bahwa pengetahuan sebagian besar responden tentang kanker serviks berpengetahuan baik dan sebagian besar karakteristik pendidikan nya adalah menengah (SMA), dan dalam hal ini, tidak menutup kemungkinan seseorang tersebut memperoleh pengetahuan dari faktor lain, tidak hanya dari faktor pendidikan saja. Faktor-faktor yang mempengaruhi pengetahuan salah satunya, yaitu usia, pengalaman, pendidikan, dan status ekonomi (Notoatmodjo, 2010).

\section{Sikap terhadap Pemeriksaan Pap Smear pada Pasien Kanker Serviks di Poliklinik Kandungan RSUD Ulin Banjarmasin.}

Hasil penelitian sikap dari 43 responden ditemukan lebih dari setengah memiliki sikap positif, yakni sebanyak $22(51,2 \%)$ orang dan sisanya hampir setengah yaitu sebanyak 21 $(48,8 \%)$ orang memiliki sikap negatif. Jumlah responden yang memiliki sikap positif dan negatif hanya selisih sebanyak 1 (satu) orang, ini menunjukkan bahwa responden yang memiliki sikap positif dan sikap negatif hampir berimbang. Hasil penelitian menunjukan lebih dari setengah responden bersikap positif tentang pemeriksaan kanker serviks bila dikaitkan dengan pengetahuan ibu yang hasilnya lebih dari setengah juga baik tentang kanker serviks sangatlah wajar. Responden yang mengetahui akan manfaat pemeriksaan untuk mendeteksi secara dini dan bahkan sebagai usaha pencegahan penyakit sangatlah wajar bersikap positif.
Hasil penelitian tentang sikap yang ditemukan ditemukan lebih dari setengah sikap responden adalah positif. Hasil penelitian ini sejalan dengan penelitian Idaria Sidabukke, dkk (2017) bersikap positif terhadap pemeriksaan pap smear. Hasil penelitian tentang sikap yang ditemukan dalam penelitian Kinanthi Estu Linad (2014), Sikap yang positif diharapkan membuat wanita berperilaku sesuai dengan pengetahuan yang dimilikinya, dalam hal ini wanita diharapkan berpartisipasi dalam program pap smear.

\section{Dukungan Suami terhadap Pemeriksaan Pap Smear pada Pasien Kanker Serviks di Poliklinik Kandungan RSUD Ulin Banjarmasin.}

Hasil penelitian dukungan suami dari 43 responden terhadap pemeriksaan kanker serviks pap smear ditemukan sebagian besar memiliki dukungan suami baik $36(83,7 \%)$ responden, dan $7(16,3 \%)$ responden memiliki dukungan suami kurang baik, dalam hal ini banyak responden yang datang melakukan pemeriksaan didampingi oleh suami.

Dalam penelitian ini sebagian besar responden mendapatkan dukungan dalam kategori baik dari suami disebabkan karena suami adalah pemimpin keluarga yang bertanggung jawab terhadap kondisi keluarga baik kondisi kesehatan, ekonomi ataupun lainya. Suami, isteri dan seluruh keluarga terutama dalam satu atap dalam keadaan saling ketergantungan, diantara tugas pokoknya memberikan/dukungan dan semangat kepada anggota keluarga terutama untuk pencegahan terjadinya penyakit seperti kanker serviks dan juga penyakit lainnya seperti stroke, hipertensi, jantung, kencing manis dan lain sebagainya. Memberikan dukungan pada isteri bagi suami merupakan salah satu wujud perilaku suami dalam memelihara dan meningkatkan kesehatan, termasuk juga tindakan-tindakan untuk mencegah terjadinya kanker serviks. Sejalan dengan hasil penelitian dalam Jurnal Kesehatan Reproduksi Kinanthi Estu Linadi (2013). Suami merupakan orang terdekat dengan responden. Dalam rumah tangga, perlakuan suami akan mempengaruhi perilaku istri. Termasuk di tempat penelitian, dukungan suami dapat berpengaruh terhadap perilaku responden. Dukungan yang dimaksud adalah dukungan 
secara sikap, bersedia mengantar ke layanan kesehatan, dukungan dana, dan dukungan persetujuan.

\section{Dukungan Petugas Kesehatan terhadap Pemeriksaan Pap Smear pada Pasien Kanker Serviks di Poliklinik Kandungan RSUD Ulin Banjarmasin.}

Penelitian tentang dukungan petugas kesehatan dari 43 responden terhadap pemeriksaan Pap Smear pada pasien kanker serviks menemukan 38 responden $(88,4 \%)$ dukungan petugas kesehatan baik, dan 5 responden $(11,6 \%)$ dukungan petugas kesehatan kurang baik. Hasil penelitian parameter yang paling tinggi adalah komunikator, dimana "petugas kesehatan menyampaikan informasi tentang kegiatan pemeriksaan kanker serviks" sebesar (47,6\%), kondisi ini disebabkan fungsi petugas adalah menyampaikan informasi terkait kegiatan yang dilaksanakan di wilayah kerjanya.

Hasil penelitian Kinanthi Estu Linad (2013) tentang dukungan petugas kesehatan didapatkan bahwa pemberian informasi dapat menjadi salah satu usaha untuk meningkatkan motivasi wanita agar lebih berperan aktif mengikuti program pap smear. Mayoritas wanita usia subur $(55,7 \%)$ atau 34 responden mendapatkan dukungan petugas kesehatan yang tinggi. Sedangkan sebanyak $(16,4 \%)$ atau 10 responden mendapat dukungan petugas kesehatan yang rendah. Tingginya dukungan petugas kesehatan disebabkan oleh aktifnya petugas kesehatan dalam memberikan informasi mengenai pemeriksaan IVA maupun mengajak WUS yang berkunjung ke puskesmas untuk melakukan pemeriksaan.

Motivasi Menjalani Pemeriksaan pap Smear pada Pasien Kanker Serviks di Poliklinik Kandungan RSUD Ulin Banjarmasin.

Berdasarkan hasil penelitian dari 43 responden menunjukkan motivasi menjalani pemeriksaan pap smear adalah 36 responden $(83,3 \%)$ motivasi tinggi dan 7 responden $(16,3 \%)$ motivasi rendah.

Hasil penelitian diatas sejalan dengan penelitia Ajeng Novita Sari (2017) yang menunjukkan bahwa ada hubungan yang bermakna antara motivasi deteksi dini kanker serviks dengan tindakan melakukan pap smear pada wanita usia subur di Wilayah Gonilan.
Hasil penelitian ini mendukung penelitian terdahulu yang menyatakan bahwa ada hubungan yang signifikan antara motivasi dengan tindakan pap smear pada wanita usia subur.

Kontribusi Pengetahuan terhadap Motivasi Menjalani Pemeriksaan Pap Smear pada Pasien Kanker Serviks di Poliklinik Kandungan RSUD Ulin Banjarmasin.

Hasil uji korelasi menunjukkan pengetahuan memiliki kontribusi yang positif terhadap motivasi pemeriksaan pap smear di Poliklinik Kandungan RSUD Ulin Banjarmasin $(0,048<0,05)$, hal ini berarti perubahan pengetahuan yang baik berkontribusi terhadap motivasi yang tinggi untuk melakukan pemeriksaan pap smear.

Berdasarkan hasil penelitian menunjukkan bahwa responden dengan tingkat pengetahuan yang tinggi hampir seluruhnya mempunyai motivasi yang tinggi melakukan pemeriksaan pap smear yaitu 22 responden $(91,7 \%)$ dari 24 responden yang memiliki pengetahuan baik, sedangkan responden yang mempunyai pengetahuan rendah sebagian besar mempunyai motivasi yang juga tinggi yaitu 14 responden $(73,7 \%)$ dari 19 responden yang memiliki pengetahuan rendah. Selisih angka antara persentasi antara pengetahuan rendah dan yang memiliki pengetahuan tinggi cukup jauh yang berarti responden yang berpengetahuan tinggi jauh lebih besar peluangnya untuk mempunyai motivasi yang tinggi bila dibandingkan dengan responden yang memiliki pengetahuan rendah. Sejalan dengan hasil penelitian yang termuat dalam Jurnal Keperawatan yang dilakukan oleh Aminah Aatinaa Adhyatma (2019) hasil uji korelasi menunjukkan ada hubungan yang signifikan antara tingkat pengetahuan wanita usia subur dengan motivasi melakukan pemeriksaan pap smear di Desa Jetis Wilayah Kerja Puskesmas Jimbaran $(0,008<0,05)$, hal ini berarti perubahan pengetahuan yang baik akan mempengaruhi motivasi yang tinggi untuk melakukan pemeriksaan pap smear.

\section{Kontribusi Sikap terhadap Motivasi Menjalani Pemeriksaan Pap Smear pada Pasien Kanker Serviks di Poliklinik Kandungan RSUD Ulin Banjarmasin.}


Hasil uji Spearman's rho didapatkan $\rho=$ $(0,033), \rho<\alpha(0,05)$, maka $\mathrm{H}_{0}$ ditolak dan dapat disimpulkan bahwa secara statistik sikap memiliki kontribusi terhadap motivasi untuk menjalani pemeriksaan pap smear pada pasien kanker serviks di Poliklinik Kandungan RSUD Ulin Banjarmasin. Ada hubungan positif yang berarti menunjukkan bahwa semakin baik sikap, maka akan semakin baik pemanfataan motivasi untuk menjalani pemeriksaan pap smear oleh responden.

Hasil penelitian sikap memiliki kontribusi terhadap pemeriksaan dini kanker serviks pap smear sejalan dengan penelitian Miftahil Fauza et, al yang berjudul "Faktor yang Berhubungan dengan Deteksi Dini Kanker Serviks Metode IVA di Puskesmas Kota Padang tahun 2019, dimana dalam penelitiannya mengungkapkan bahwa terdapat hubungan yang signifikan antara sikap dengan deteksi dini kanker serviks.

Kontribusi Dukungan Suami terhadap Motivasi Menjalani Pemeriksaan pap smear pada Pasien Kanker serviks di Poliklinik Kandungan RSUD Ulin Banjarmasin.

Hasil uji Spearman's rho kontribusi dukungan suami terhadap motivasi menjalani pemeriksaan pap smear pada pasien kanker serviks di Poliklinik Kandungan RSUD Ulin Banjarmasin dengan $\rho=0,000<0,05$.

Hasil penelitian ini menunjukkan adanya kontribusi yang positif dukungan suami terhadap pemeriksaan pap smear karena dukungan suami dapat memberi semangat atau saling memberi semangat dalam rumah tangga dalam bentuk memberi dukungan secara instrumental, informatif, emosional dan harga diri. Secara psikologis masing-masing anggota keluarga terutama yang memiliki atau berisiko memiliki masalah kesehatan (sakit) akan merasa mendapat perhatian dan kasih sayang dari anggota keluarganya yang lain khususnya suami, sehingga akan lebih bersemangat dan termotivasi untu lebih menjaga kesehatannya.

Hasil penelitian yang didapatkan menemukan adanya kontribusi dukungan suami terhadap motivasi menjalani pemeriksaan kanker serviks pap smear pada pasien kanker serviks di Poliklinik Kandungan RSUD Ulin Banjarmasin sejalan dengan penelitian yang dilakukan oleh Miftahil Fauza et, al (2019) yang menemukan adanya dukungan suami terhadap pemeriksaan dini kanker serviks pap smear.

\section{Kontribusi Dukungan Petugas Kesehatan terhadap Motivasi Menjalani Pemeriksaan Pap Smear pada Pasien Kanker Serviks di Poliklinik Kandungan RSUD Ulin Banjarmasin.}

Hasil analisis uji Spearman's rho $\rho=0,000$ menunjukkan dukungan petugas kesehatan berkontribusi terhadap motivasi untuk menjalani pemeriksaan pap smear pada pasien kanker serviks di Poliklinik Kandungan RSUD Ulin Banjarmasin.

Hasil penelitian yang didapat dukungan petugas kesehatan memiliki kontribusi terhadap motivasi pemeriksaan pap smear karena motivasi masyarakat (responden) dapat lebih ditingkatkan lagi apabila petugas kesehatan mampu memberikan penyuluhan, khususnya mengenai manfaat pap smear untuk deteksi dini kanker serviks. Dukungan sebagai komunikator yaitu petugas memberikan informasi masyarakat, petugas memotivator bahaya kanker serviks dapat diketahui secara dini dengan melakukanpemeriksaan pap smear, petugas kesehatan berperan sebagai fasilitator dengan memberikan menyediakan tempat yang nyaman untuk kegiatan pemeriksaan pap smear sebagai konselor bahwa mereka menerima saran tentang kegiatan pemeriksaan pap smear yang telah berjalan. Hasil penelitian ini mengungkapkan bahwa dukungan petugas kesehatan berkontribusi terhadap motivasi untuk menjalani pemeriksaan pap smear pada pasien kanker serviks sejalan dengan penelitian yang dilakukan oleh Umayana \& Cahyati (2014) dimana dalam penelitiannya menemukan adanya hubungan antara dukungan petugas kesehatan dengan ppemeriksaan kanker serviks.

\section{Faktor yang Paling Berkontribusi terhadap Motivasi Menjalani Pemeriksaan Pap Smear pada Pasien Kanker Serviks di Poliklinik Kandungan RSUD Ulin Banjarmasin.}

Hasil penelitian terkait variabel yang paling berkontribusi terhadap pemeriksan pap smear adalah dukungan petugas kesehatan nilai korelasi koefisien yang didapatkan adalah 0,823 artinya sebesar $82,3 \%$ dukungan petugas berkontribusi terhadap pemeriksaan dini kanker 
serviks pap smear, dukungan suami $\mathrm{r} 0,659 \mathrm{p}$ yang artinya responden yang memiliki dukungan suami tinggi $65,9 \%$ berpeluang memiliki motivasi untuk melakukan pemeriksaan dini kanker serviks, sikap r 0,325 yang artinya responden yang memiliki dukungan suami tinggi $32,5 \%$ berpeluang memiliki motivasi untuk melakukan pemeriksaan dini kanker serviks, sikap nilai $r$ 0,242 , yang artinya motivasi pemeriksaan dini kanker serviks responden yang memiliki sikap positif $24,2 \%$ berpeluang memiliki motivasi untuk melakukan pemeriksaan dini kanker serviks.

Hasil penelitian ini menunjukkan bahwa dukungan petugas kesehatan sangat berperan dan saling berkaitan terhadap faktor yang lain dalam memberikan motivasi terhadap responden untuk melakukan pemeriksaan pap smear. Pengetahuan responden tentang kanker servik banyak didapatkan melalui penyuluhan yang disampaikan oleh petugas kesehatan sehingga adanya sikap positif dari responden untuk memeriksakan dirinya yang melibatkan suami untuk mendampingi dan memberikan motivasi kepada istri untuk melakukan pemeriksaan pap smear.

\section{KESIMPULAN}

Pengetahuan, sikap, dukungan suami, dukungan petugas kesehatan dan motivasi tentang penyakit kanker serviks dan pemeriksaan kanker serviks pap smear pada pasien kanker serviks besar, di Poliklinik Kandungan RSUD Ulin Banjarmasin.

Pengetahuan, sikap, dukungan suami dan dukungan petugas kesehatan berkontribusi terhadap motivasi menjalani pemeriksaan pap smear pada pasien kanker serviks di Poliklinik Kandungan RSUD Ulin Banjarmasin.

Faktor yang paling berkontribusi terhadap motivasi menjalani pemeriksaan pap smear pada pasien kanker serviks adalah dukungan petugas kesehatan di Poliklinik Kandungan RSUD Ulin Banjarmasin.

Hasil penelitian ini dapat menjadi masukan kepada seluruh petugas kesehatan agar lebih meningkatkan promosi kesehatan dalam pemberdayaan masyarakat khususnya tentang pemeriksaan dini untuk meningkatkan motivasi pasien kanker serviks. Pelayanan kesehatan juga diharapkan dapat mengoptimalkan kegiatan seperti memberikan penyuluhan tentang pemeriksaan dini terhadap wanita usia subur, memberikan informasi tentang penyebab dan pencegahan kanker serviks, serta meningkatkan motivasi pasien kanker serviks dalam melakukan pemeriksaan pap smear.

\section{ACKNOWLEDGMENT}

Ucapan terima kasih yang sebesar-besarnya bagi seluruh responden yang sudah dengan sangat baik membantu menyukseskan kegiatan penelitian ini. Terima kasih juga kepada Kepala Ruangan dan Staff perawat maupun bidan Poliklinik Kandungan RSUD Ulin Banjarmasin yang sudah sangat mendukung terselesaikannya penelitian ini.

\section{DAFTAR PUSTAKA}

American Cancer Society, 2017. Data sources: Surveillance, Epidemiology, and End Results (SEER) 18 registries, National Cancer Institute, 2016. Atlanta : The American Cancer Society is a qualified 501(c)(3) tax-exempt organization.

Ajeng Novita Sari (2017). Correlation Between Motivation of Early Cervix Cancer Detection with Pap Smear Examination Behavior in Reproductive Age of Women in Gonilan District. [Jurnal]. JOMIS (Journal Of Midwifery Science).

Brida Kity Dinarum, Herlin Fitriana K (2017). Faktor- Faktor Yang Berhubungan Dengan Pemeriksaan Deteksi Dini Kanker Serviks Metode Inspeksi Visual Asam Asetat (Iva) Di Wilayah Kerja Puskesmas Buayan Kebumen.

Cholifah, Rusnoto \& Hidayah. (2017). Faktor yang Mempengaruhi Deteksi Dini Kanker Serviks. [Jurnal]. Jurnal University Research Colloquium. Universitas Muhammadiyah Magelang.

Dinas Kesehatan Provinsi Kalsel. (2019). Laporan Penyakit Tidak Menular Tahun 
2017. Banjarmasin. Dinas Kesehatan Kalimantan Selatan.

Een Kurnaesih et,al (2018).Gambaran Karakteristik Penderita Kanker Serviks Berdasarkan Faktor Resiko di RSU Sumedang. [Jurnal]. Jurnal. IJMS Indonesian Journal on Medical Science.

Fauza, Aprianti \& Azrimaidaliza. (2019). Faktor yang Berhubungan dengan Deteksi Dini Kanker Serviks Metode IVA di Puskesmas Kota Padang. [Jurnal]. Jurnal Promosi Kesehatan Indonesia.

Idaria Sidabukke et,al (2017). Faktor - Faktor yang Berhubungan dengan Minat WUS Melakukan Deteksi Dini Kanker Leher Rahim di Puskesmas Tanjung Marulak Kota Tebing Tinggi

Indri Ramadini (2018). Hubungan Deteksi Dini (Pap Smear) Dengan Kejadian Kanker Serviks Di Poli Obgyn Padang, Indonesia. Jurnal Endurance.

Kemenkes RI. (2017). Lindungi Perempuan Indonesia Dari Kanker Serviks dan Kanker Payudara. Jakarta: Kemenkes RI.

Kinanthi Estu Linadi (2013). Dukungan Suami Mendorong Keikutsertaan Pap Smear Pasangan Usia Subur (Pus) Di Perumahan Pucang Gading Semarang.

Notoatmodjo S. (2010). Promosi Kesehatan dan Ilmu Perilaku. Metodelogi Penelitian Kesehatan. Jakarta: Rineka Cipta.

Nonik Ayu Wantini \& Novi Indrayani (2018). Deteksi Dini Kanker Serviks dengan Inspeksi Visual Asam Asetat (IVA). Fakultas Ilmu Kesehatan, Universitas Respati Yogyakarta, Indonesia. Jurnal Ners dan Kebidanan.

Oktavyany, S \& Ratnaningsih, D. (2015). Hubungan Tingkat Pengetahuan tentang Kanker Serviks dengan Sikap Terhadap Pemeriksaan Pap Smear Pada PUS Di Puskesmas Semanu Gunung kidul.
Reni Heryani (2018). Hubungan Pengetahuan Wanita Terhadap Pemeriksaan Papsmear Di Wilayah Puskesmas Garuda Kota Pekanbaru.

Ridarti \& Gita (2015). Gambaran Pengetahuan Dan Dukungan Suami Tentang Pemeriksaan Pap Smear Pada Pasangan Usia Subur Di Desa Sungai Cemara Kecamatan Sadu Kabupaten Tanjung Abung Timur Tahun 2014

RSUD Ulin Banjarmasin (2019). Buku Register Kunjungan Pasien Kanker Serviks 2019. Banjarmasin: Poliklinik Kandungan RSUD Ulin Banjarmasin

Silfia \& Muliati. (2017). Hubungan Karakteristik, Pengetahuan dan Sikap dengan Pemeriksaan Inspeksi Visual Asam Asetat (IVA) pada Ibu Pasangan Usia Subur di Puskesmas Talise. Jurnal CARING.

Universitas Muhammadiyah Bamjarmasin. (2019). Buku Panduan Penyusunan Tesis Kuantitatif Banjarmasin: Magister Ilmu Keperawatan Program Pasca Sarjana Universitas Muhammadiyah Banjarmasin.

Yayasan Kanker Indonesia, 2016. Penderita Kanker Indonesia Semakin Meningkat. Diakses pada 22 Agustus 2019, dari alamat http://kanker_insiden.com. $241 \mathrm{html}$ Yayasan Kanker Indonesia (2017). Kanker Biisa Diicegah,, Deteksi Dini Kanker Payudara dan Serviks Ditanggung Pemerintah. Jakarta: Yayasan Kanker Serviks Indonesia. 